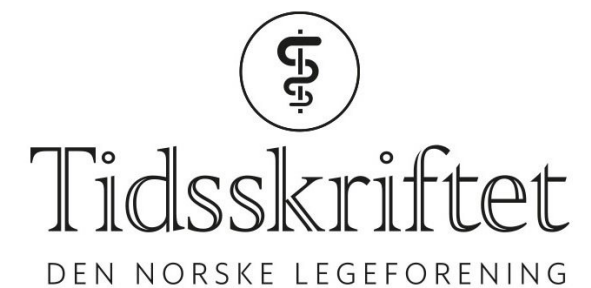

DEN NORSKE LEGEFORENING

\title{
FHI overvåker infeksjoner gjennom diagnosekodene på regningskort
}

KOMMENTAR

\section{GRY GRøNENG}

E-post: GryMarysol.Groneng@fhi.no

Gry Grøneng er seniorrådgiver ved Folkehelseinstituttet.

\section{TRINE HESSEVIK PAULSEN}

Ingen av forfatterne har oppgitt noen interessekonflikter.

Takk til forfatterne av artikkelen «Allmennlegers bruk av ICPC-diagnoser og samsvar med journalnotatene» (1) for at de har undersøkt kvalitet og intern koherens vedrørende bruken av takster fra ICPC kodeverket, og for formidlingen av dette. Artikkelen påpeker at kvaliteten på allmennlegenes diagnosesetting har betydning fordi de benyttes til kvalitetsforskning, forskning og i offentlige statistikker. Denne bruken av KUHR-data tror vi kunne vært bedre kjent. I tillegg har bruken en annen dimensjon som vi ønsker å belyse.

Data fra KUHR-databasen brukes av Folkehelseinstituttet i overvåking av smittsomme sykdommer. Dataene på regningskortene blir anonymisert av Helsedirektoratet før de automatisk blir sendt til Folkehelseinstituttet (FHI) og overvåkningssystemet Sykdomspulsen. Der blir dataene videre bearbeidet og statistiske analyser blir utført før dataene brukes i overvåking. Blant annet brukes datagrunnlaget til å bestemme nivået av influensalignende sykdom i Norge gjennom influensasesongen. Disse dataene publiseres ukentlig av FHI gjennom hele influensasesongen (uke 40 - uke 20). Dataene brukes også til pilotprosjektet «Sykdomspulsen til kommunehelsetjenesten», hvor utvalgte kommuneoverleger har fått tilgang til en interaktiv webside der de kan følge med på magetarminfeksjoner og luftveisinfeksjoner i blant annet sin egen kommune. Dette kan bidra til å oppdage lokale utbrudd av f.eks. vannbåren smitte. Erfaringene fra piloten er svært gode og FHI jobber nå for å etablere en sikker og robust produksjonsløsning så alle kommuneoverleger i Norge vil få tilgang til tjenesten.

Denne studien er viktig for vår bruk av diagnosedata i overvåkingen, og vi setter stor pris på at diagnosekodene er i samsvar med legens vurdering som formidlet $\mathrm{i}$ journalen. Det viser at sykdomsovervåkingen som munner ut fra KUHR er pålitelig, og samtidig fordrer det til ytterligere bruk av KUHR-data.

\section{LITTERATUR:}

1. Sporaland GL, Mouland G, Bratland B et al. Allmennlegers bruk av ICPC-diagnoser og samsvar med journalnotatene. Tidsskr Nor Legeforen 2019;139. doi:10.4045/tidsskr.18.0440. [PubMed][CrossRef] 
Publisert:3. februar 2020. Tidsskr Nor Legeforen. DOI: 10.4045/tidsskr.20.0027

(C) Tidsskrift for Den norske legeforening 2020. Lastet ned fra tidsskriftet.no 